\title{
Advances in Vaccine Development Against Sporotrichosis
}

\author{
Sandro Rogerio de Almeida ${ }^{1,2}$
}

Published online: 29 May 2019

(C) Springer Nature Switzerland AG 2019

\begin{abstract}
Purpose of Review To review recent data about the study of the immune response in sporotrichosis and recent progress in the development of an effective human and feline vaccine.

Recent Finding The cell wall of Sporothrix is an important source of antigens with the potential to develop vaccines. A major candidate is a $70-\mathrm{kDa}$ glycoprotein (gp70). Our group developed a model of sporotrichosis treatment using the monoclonal against gp70 (mAbP6E7) with good results. We also recently developed a humanized antibody, mAbP6E7, that increased phagocytosis in human monocytes and reduced the fungal burden in a murine model of sporotrichosis. The other importance the study demonstrated is the protective capacity of an enolase-based vaccine and Montanide ${ }^{\mathrm{TM}}$ Pet Gel A (PGA) as an adjuvant against $S$. schenckii. The use of an immunoproteomic approach demonstrated the efficacy of three peptides as a vaccine to promote a protective immune response against sporotrichosis that aid the development of novel therapeutic approaches against fungal infections.

Summary Several diseases have been eradicated with the use of vaccines, but the development of vaccines against fungal infections in humans and animals remains a challenge, in part due to a lack of knowledge about the mechanisms of protective immunity against fungal infections and the genetic complexity of fungi. In this review, we discuss recent advances in vaccine development against sporotrichosis.
\end{abstract}

Keywords Sporothrix spp. $\cdot$ Sporotrichosis $\cdot$ Antibodies $\cdot$ Vaccine-host immunity $\cdot$ Tropical mycosis $\cdot$ Vaccines $\cdot$ Immunotherapy

\section{Sporotrichosis: the Current Situation}

\section{Human Sporotrichosis}

Sporotrichosis is a chronic subcutaneous mycosis affecting humans and animals that, in some cases, may disseminate [1]. Sporotrichosis is caused by the thermodymorphic fungus Sporothrix spp., which presents as a mycelial form (saprophytic) at $25^{\circ} \mathrm{C}$ and a yeast form (parasitic) at $37^{\circ} \mathrm{C}[2]$. This transition, which is induced by temperature, is an important

This article is part of the Topical Collection on Tropical Mycoses

Sandro Rogerio de Almeida sandroal@usp.br

1 Department of Clinical and Toxicological Analysis, Faculty of Pharmaceutical Sciences, University of São Paulo, São Paulo, Brazil

2 Departamento de Análises Clínicas e Toxicológicas, Faculdade de Ciências Farmacêuticas, Universidade de São Paulo, Avenida Prof. Lineu Prestes, 580, Bloco 17, São Paulo CEP: 05508-900, Brazil morphological adaptation to infection in mammals. The transmission of the disease is associated with the inoculation of conidia or yeasts in the subcutaneous tissue by means of a trauma involving decaying plants or scratches from diseased or contaminated cats [3]. For a long time, transmission of the disease was thought to be strictly related to a trauma in the subcutaneous tissue, but there have been reports of airborne transmission [4]. Antifungals are the main choices for the treatment of fungal infections in immunosuppressed and immunocompetent patients. However, recurring resistance to almost all antifungal drugs has been reported [5]. Sporotrichosis is the most common subcutaneous mycosis in Latin America [1].

For more than 100 years, S. schenckii was described as the only species responsible for sporotrichosis. However, in 2006, through phylogenetic analyses of the sequences of calmodulin genes, a new species of Sporothrix spp. was determined $[6 \bullet \bullet]$. According to de Beer et al., to facilitate future studies, clinically relevant species were separated into a pathogenic clade (pathogenic agents in humans) including S. brasiliensis, S. schenckii, S. globosa, and S. luriei [7]. 
Although disease occurs worldwide, most cases are reported in tropical and subtropical zones in Latin America, Africa, and Asia. In endemic regions, this disease is mainly associated with plant transmission, with the main etiologic agents being S. schenckii and S. globosa [8].

\section{Cat Sporotrichosis and Zoonotic Transmission}

The zoonotic transmission of sporotrichosis has gained great importance after cases were reported in Brazil, which differs from other outbreaks that occurred in other parts of the world, where the source of the infection was soil and decomposing plant matter $[9 \bullet, 10]$. Some cases of sporotrichosis transmission by animals have been described in other countries, involving accidents with snakes, birds, and squirrels and the hunting of armadillos [11]. In Brazil, the transmission of the disease by cats caused a large epidemic in Rio de Janeiro [9•]. For example, the largest zoonotic outbreak of sporotrichosis occurred in the state of Rio de Janeiro [1]. According to the Evandro Chagas Clinical Research Institute, Fiocruz, between 1998 and 2009, more than 2000 cases were in humans and 3000 cases in cats were registered [12]. In another study, between 1998 and 2001, approximately $86 \%$ of sporotrichosis cases were reported in patients who had professional or domestic contact with contaminated cats [9•]. Because of this, the disease became endemic in the state of Rio de Janeiro. Currently, the situation regarding sporotrichosis in the state of Rio de Janeiro is alarming. There was a $400 \%$ increase in the number of cases of feline sporotrichosis in 2016 when compared to those in 2015, revealing the significant expansion of the disease. In 2016, approximately "13,500" cases of sporotrichosis were reported, which is 10,000 more than in the previous year [9•]. Since 2013, the notification of sporotrichosis is mandatory in the state of Rio de Janeiro but not in other Brazilian states. Another serious problem is an effective feline treatment. In feline sporotrichosis, treatment involves the use of different drug protocols that include potassium iodide and itraconazole [13]. Treatment may take several months and is challenging due to the difficulty of providing medical care to stressed cats that can scratch and infect their owners and caregivers. Therefore, it is imperative to develop a vaccine to prevent or treat cats and humans infected with Sporothrix spp.

In this review, we discuss some recent information about the development of an effective human and feline vaccine.

\section{Immune Response Against Sporothrix spp.}

The immune response can be divided into innate and acquired immune responses. The innate immune response is the host's first line of defense, in which PRRs recognize pathogenassociated molecular patterns (PAMPs), inducing a rapid and essential response in the initial hours of infection. In the acquired immune response, the participation of CD4 T cells is fundamental in the control of the disease. Current available data on the immune response to Sporothrix spp. is predominantly based on in vitro studies and mouse experimental models, and data gathered directly from human patients are scarce. However, there is a consensus that the host immune response is essential in the control of sporotrichosis [14] [15] [16].

Macrophages play an essential role in the innate response to sporotrichosis. The activation of macrophages induces phagocytosis and promotes the production of proinflammatory cytokines, such as IL- 6 , TNF- $\alpha$, and IL- $1 \beta$, increasing the microbicidal activity of macrophages by ROS (reactive oxygen species) such as NO (nitric oxide), which is highly cytotoxic to $S$. schenckii [17]. The conidia of $S$. schenckii induce low ROS production, favoring the dimorphic transition from conidia to yeasts [18]. Mannose receptors play a role in the recognition of $S$. schenckii, promoting a response from Th1 cells during the disease [19]. The mannose receptor is also related to the Th1 response to other diseases caused by fungi [20]. The role of dectin-1 has also been investigated in sporotrichosis, and $\beta$-1-3-glucan recognition induces an increase in the production of cytokines such as IL-1 $\beta$ and IL-18 [21]. An increase in IL-1 $\beta$ and IL-18 in sporotrichosis is related to the activation of caspase-1, suggesting the participation of inflammatory and NOD (nucleotide oligomerized domain) receptors [22].

The TLRs (toll-like receptors) are part of a conserved transmembrane receptor family that contains an external membrane domain with particular leucine-rich sequences in each TLR. Recent studies have demonstrated that lipid extracts from S. schenckii yeast bind to TLR-4, which leads to ROS induction [23]. Macrophages from TLR-4 knockout animals were unable to produce high levels of cytokines such as IL-1, IL-12, and TNF- $\alpha$ [24]. Kajiwara et al. argued that TLR-4 is the main receptor against $S$. schenckii in its localized cutaneous form because it is capable of inducing a Th1 response with the production of proinflammatory cytokines [25]. Recently, our laboratory showed that TLR-4 is required for optimal host responses to $S$. brasiliensis. A lack of TLR-4 signaling impairs phagocytosis and the release of cytokines and antimicrobial mediators by macrophages, confirming the role of the TLR-4 signaling pathway in S. brasiliensis infection [26].

Negrini et al. investigated the role of TLR-2 during S. schenckii infection over a period of 10 weeks; they observed the influence of TLR-2 overproduction on IL- $1 \beta$, IL12 , and TNF- $\alpha$ levels in macrophages in spleen cells, as measured by NO release and the production of IFN- $\gamma$, IL-6, IL-17, and TGF- $\beta$ [27]. In our lab, we evaluated the importance of TLR-2 during $S$. brasiliensis infection. In vitro assays using bone marrow-derived macrophages (BMDMs) from both wild-type (C57BL/6) and TLR-2 knockout $\left({ }^{-/}\right)$mice showed 
that the absence of TLR-2 resulted in impaired phagocytosis and microbicide mechanisms that utilize NO. However, this did not affect in vitro cytokine production. In vivo assays demonstrated that the absence of TLR-2 during experimental $S$. brasiliensis infection promoted the increased dissemination of $S$. brasiliensis after 14 and 28 days and polarized the Th17 response to control infection [28].

Several studies reported the importance of the cellular immune response in sporotrichosis. Patients deficient in this type of response have more severe forms of the disease [2]. The absence of an adaptive immune response increases mortality from experimental sporotrichosis [14]. CD4 ${ }^{+} \mathrm{T}$ lymphocytes secrete several cytokines, such as IFN- $\gamma$, TNF- $\alpha$, and IL-17A, that determine host resistance against fungal infections, such as aspergillosis and candidiasis [29] [30]. The Th1 response is characterized by the release of IFN- $\gamma$, a strong macrophage activator that is fundamental in the control of sporotrichosis [31].Th17 cells play a role in the defense against extracellular bacteria and fungi and have both protective and deleterious effects [32]. The Th17 response promotes the secretion of IL17 , which has pro-inflammatory activities including neutrophil recruitment and the production of pro-inflammatory cytokines by epithelial cells. Using a murine experimental model of $S$. schenckii infection, it was confirmed that the absence of the Th17 response is related to higher lethality during infection [33]. Th17 cells eliminate $S$. schenckii in mice during systemic infection, and IL-23 depletion leads to an increase in fungal load. In vitro studies showed that dendritic cells (DCs) recognize S. schenckii antigens, which leads to the development of a mixed Th1/Th17 pattern [31]. The $S$. schenckii exoantigen increases the levels of inflammatory cytokines produced by macrophages and DCs. Therefore, the coincubation of $\mathrm{T}$ cells with exoantigen-activated DCs provoked the secretion of Th1/Th17 cytokines (IFN- $\gamma /$ Th17, IL-23, and TGF- $\beta$ ). CD4 $4^{+}$Th1 and Th17 cells are fundamental elements in the immune response against $S$. schenckii [33].

\section{Vaccine and Immunotherapy}

Several diseases have been eradicated with the use of vaccines, such as smallpox in humans and rinderpest on animals, along with the near eradication or successful prevention of other viral or bacterial infections $[34,35]$. However, the development of vaccines against fungal infections remains a challenge, in part due to a lack of knowledge about the mechanisms of protective immunity against fungal infections and the genetic complexity of fungi [5]. Currently, only 2 antigens are in clinical trials for the creation of a new vaccine against fungal infections, both of which are for candidiasis [36] [37] [38]. Fungal infections are an emerging group of infectious diseases. Chronic conditions, such as AIDS, the increased use of chemotherapy in cancer treatment, and other factors that decrease the host immune response, along with invasive hospital procedures, such as catheter use, significantly increase the number of cases of disseminated fungal infection [39] [40]. Antifungal drugs that treat mycosis are most often used in immunocompetent and immunosuppressed patients. However, drug resistance in fungal infections has been reported for almost all antifungal drugs [41]. A vaccine that induces a protective immune response against fungi with or without an antifungal drug could promote resistance in the host and be a better approach to treat fungal infection.

The cell wall of Sporothrix is an important source of antigens with the potential to develop vaccines. A major candidate is a 70-kDa glycoprotein (gp70). We showed that mice infected with $S$. schenckii were able to produce a high level of antibodies against gp70 and decrease the number of CFUs, indicating its participation in infection control [42]. A similar glycoprotein of $70 \mathrm{kDa}$ with a $\mathrm{pI}$ (isoelectric point) of 4.1 and approximately $5.7 \%$ of its molecular mass composed of $\mathrm{N}$ glycans was identified and purified by Ruiz-Baca et al. [43].

The use of antibodies to neutralize infection without inducing an active memory immune response by the host is another way to combat pathogens. Some antibodies have shown antifungal activity and synergy with antifungals with good results. Our group developed a model of sporotrichosis treatment using the monoclonal antibody P6E7, a monoclonal antibody against gp70 [44••]. MAbP6E7 is effective against sporotrichosis in prophylactic and therapeutic models of infection by S. schenckii and S. brasiliensis [45]. We also recently developed a humanized antibody, mAbP6E7, that increased phagocytosis in human monocytes and reduced the fungal burden in a murine model of sporotrichosis [46], demonstrating that gp70 is an important therapeutic target for the treatment of sporotrichosis.

Portuondo et al., in a study of the immunogenicity of cell wall proteins from $S$. schenckii (ssCWP), showed that the passive transference of anti-ssCWP serum from high-dose aluminum hydroxide-adjuvanted formulatin afforded in vivo protection against subsequent challenge with $S$. schenckii, making it a viable vaccine candidate for further testing [47]. Similarly, Chen et al. developed a potential candidate S. globosa vaccine using a recombinant phage with a gp70 peptide. This recombinant phage enhanced Th1 cells and induced a strong humoral response that decreased the fungal load in disseminated sporotrichosis caused by S. globosa $[48 \cdot \bullet]$.

The comparative efficacy and toxicity of two vaccine candidates against $S$. schenckii using either Montanide ${ }^{\mathrm{TM}}$ Pet Gel A (PGA) or aluminum hydroxide adjuvants in mice has been also evaluated. The PGA adjuvant induced an efficient immune response and was safe for use as a future sporotrichosis vaccine [49]. Recently, the same group showed the protective capacity of an enolase-based vaccine and PGA as an adjuvant against $S$. schenckii with increased virulence following 
exposure to toluene. The adjuvanted vaccine induced a strong, specific Th1 response and protective immunity against challenge with either wild-type or toluene-adapted $S$. schenckii in $\mathrm{Balb} / \mathrm{c}$ mice. These studies highlight the role of the adjuvant PGA in driving the increasing of anti-Sporothrix immunity and as the key component in vaccine efficacy [50].

Chen et al. extracted an antibody against hybrid phage nanofibers (phage-KR) from immunized mice and passively inoculated Sporothrix globosa (S. globosa)-infected mice. The antibody efficiently inhibited $S$. globosa infection, reduced the progression of fungal colonization, increased the animal survival rate, and relieved organ inflammation in the mice. The results indicate that antibodies against phage-KR may be a potential strategy for the safe and efficient treatment of $S$. globosa infections [48••].

Using an immunoproteomic approach, our group identified antigenic proteins from $S$. brasiliensis and classified peptides that can couple to MHC class II molecules to develop an effective immune response $[51 \bullet \bullet]$. We showed that some antigenic peptides, such as ZR3, ZR4, and ZR8, induced proliferation in T cells sensitized by $S$. brasiliensis. We also demonstrated that treatment with these peptides decreased the diameter of the lesions in subcutaneous sporotrichosis. The ZR8 peptide promoted increased levels of cytokines (IFN- $\gamma$, IL$17 \mathrm{~A}$, and IL-1 $\beta$ ) in lesions and increased $\mathrm{CD}^{+} \mathrm{T}$ cells in the lymph nodes and spleen. Together, these data demonstrated the efficacy of these peptides as a vaccine to promote a protective immune response against sporotrichosis that aid the development of novel therapeutic approaches against fungal infections $[51 \bullet \cdot$.

\section{Concluding Remarks}

Fungal diseases became a major medical problem in the second half of the twentieth century when advances in modern medicine together with the HIV epidemic resulted in large numbers of individuals with impaired immunity. Fungal diseases are difficult to manage because they tend to be chronic, difficult to diagnose, and difficult to eradicate with antifungal drugs. However, the development of effective vaccines against fungi is very difficult. Their genetic complexity, limited knowledge of the mechanisms of anti-fungal drugs, and the lack of a defined antigen are some of the constrains for not having an effective antifungal vaccine. For an effective vaccine, a protective immune response is essential [52]. Currently, endemic sporotrichosis is affecting cats in Brazil and may progress to zoonotic transmission in humans. Unfortunately, there is no an effective vaccine available to control this infection in cats. Therefore, it makes sense to invest in a vaccine for sporotrichosis, especially for cats. Several studies are under way, and we hope that, in the near future, we will produce an effective vaccine to combat sporotrichosis.

\section{Compliance with Ethical Standards}

Conflict of Interest The author declares no conflict of interest.

Human and Animal Rights and Informed Consent This article does not contain any studies with human or animal subjects performed by any of the authors.

\section{References}

Papers of particular interest, published recently, have been highlighted as:

- Of importance

•. Of major importance

1. Orofino-Costa R, Macedo PM, Rodrigues AM, BernardesEngemann AR. Sporotrichosis: an update on epidemiology, etiopathogenesis, laboratory and clinical therapeutics. An Bras Dermatol. 2017;92(5):606-20. https://doi.org/10.1590/abd18064841.2017279.

2. Queiroz-Telles F, Buccheri R, Benard G. Sporotrichosis in immunocompromised hosts. J Fungi (Basel). 2019;5(1). https://doi.org/ 10.3390/jof5010008.

3. Ramirez-Soto MC, Aguilar-Ancori EG, Tirado-Sanchez A, Bonifaz A. Ecological determinants of sporotrichosis etiological agents. J Fungi (Basel). 2018;4(3). https://doi.org/10.3390/jof4030095.

4. Conceicao-Silva F, Morgado FN. Immunopathogenesis of human sporotrichosis: what we already know. J Fungi (Basel). 2018;4(3). https://doi.org/10.3390/jof4030089.

5. Garcia-Carnero LC, Perez-Garcia LA, Martinez-Alvarez JA, Reyes-Martinez JE, Mora-Montes HM. Current trends to control fungal pathogens: exploiting our knowledge in the host-pathogen interaction. Infect Drug Resist. 2018;11:903-13. https://doi.org/10. 2147/IDR.S170337.

6.• Marimon R, Gene J, Cano J, Trilles L, Dos Santos Lazera M, Guarro J. Molecular phylogeny of Sporothrix schenckii. J Clin Microbiol. 2006;44(9):3251-6. https://doi.org/10.1128/JCM. 00081-06. This article establishes through phylogenetic analyses of the sequences of calmodulin genes, a new species of Sporothrix spp.

7. de Beer ZW, Duong TA, Wingfield MJ. The divorce of Sporothrix and Ophiostoma: solution to a problematic relationship. Stud Mycol. 2016;83:165-91. https://doi.org/10.1016/j.simyco.2016. 07.001 .

8. Watanabe M, Hayama K, Fujita H, Yagoshi M, Yarita K, Kamei K, et al. A case of sporotrichosis caused by Sporothrix globosa in Japan. Ann Dermatol. 2016;28(2):251-2. https://doi.org/10.5021/ ad.2016.28.2.251.

9. Lopes-Bezerra LM, Mora-Montes HM, Zhang Y, Nino-Vega G, Rodrigues AM, de Camargo ZP, et al. Sporotrichosis between 1898 and 2017: the evolution of knowledge on a changeable disease and on emerging etiological agents. Med Mycol. 2018;56(suppl 1):126-43. https://doi.org/10.1093/mmy/myx103. Provides a update about Sporotrichosis and importants knowledge of emerging etiologic species.

10. Brandolt TM, Madrid IM, Poester VR, Sanchotene KO, Basso RP, Klafke GB, et al. Human sporotrichosis: a zoonotic outbreak in southern Brazil, 2012-2017. Med Mycol. 2018. https://doi.org/10. 1093/mmy/myy082. 
11. Wenker CJ, Kaufman L, Bacciarini LN, Robert N. Sporotrichosis in a nine-banded armadillo (Dasypus novemcinctus). J Zoo Wildl Med. 1998;29(4):474-8.

12. Boechat JS, Oliveira MME, Almeida-Paes R, Gremiao IDF, Machado ACS, Oliveira RVC, et al. Feline sporotrichosis: associations between clinical-epidemiological profiles and phenotypicgenotypic characteristics of the etiological agents in the Rio de Janeiro epizootic area. Mem Inst Oswaldo Cruz. 2018;113(3): 185-96. https://doi.org/10.1590/0074-02760170407.

13. Reis EG, Schubach TM, Pereira SA, Silva JN, Carvalho BW, Quintana MS, et al. Association of itraconazole and potassium iodide in the treatment of feline sporotrichosis: a prospective study. Med Mycol. 2016;54(7):684-90. https://doi.org/10.1093/mmy/ myw027.

14. Tachibana T, Matsuyama T, Mitsuyama M. Involvement of CD4+ T cells and macrophages in acquired protection against infection with Sporothrix schenckii in mice. Med Mycol. 1999;37(6):397-404.

15. Shiraishi A, Nakagaki K, Arai T. Role of cell-mediated immunity in the resistance to experimental sporotrichosis in mice. Mycopathologia. 1992;120(1):15-21.

16. Freitas DF, de Siqueira Hoagland B, do Valle AC, Fraga BB, de Barros MB, de Oliveira Schubach A, et al. Sporotrichosis in HIVinfected patients: report of 21 cases of endemic sporotrichosis in Rio de Janeiro, Brazil. Med Mycol. 2012;50(2):170-8. https://doi. org/10.3109/13693786.2011.596288.

17. Carlos IZ, Sgarbi DB, Santos GC, Placeres MC. Sporothrix schenckii lipid inhibits macrophage phagocytosis: involvement of nitric oxide and tumour necrosis factor-alpha. Scand J Immunol. 2003;57(3):214-20.

18. Carlos IZ, Zini MM, Sgarbi DB, Angluster J, Alviano CS, Silva CL. Disturbances in the production of interleukin-1 and tumor necrosis factor in disseminated murine sporotrichosis. Mycopathologia. 1994;127(3):189-94.

19. Guzman-Beltran S, Perez-Torres A, Coronel-Cruz C, TorresGuerrero H. Phagocytic receptors on macrophages distinguish between different Sporothrix schenckii morphotypes. Microbes Infect. 2012;14(12):1093-101. https://doi.org/10.1016/j.micinf. 2012.06.001.

20. Vautier S, Sousa Mda G, Brown GD. C-type lectins, fungi and Th17 responses. Cytokine Growth Factor Rev. 2010;21(6):405-12. https://doi.org/10.1016/j.cytogfr.2010.10.001.

21. Martinez-Alvarez JA, Perez-Garcia LA, Mellado-Mojica E, Lopez MG, Martinez-Duncker I, Lopes-Bezerra LM, et al. Sporothrix schenckii sensu stricto and Sporothrix brasiliensis are differentially recognized by human peripheral blood mononuclear cells. Front Microbiol. 2017;8:843. https://doi.org/10.3389/fmicb.2017.00843.

22. Goncalves AC, Ferreira LS, Manente FA, de Faria C, Polesi MC, de Andrade CR, et al. The NLRP3 inflammasome contributes to host protection during Sporothrix schenckii infection. Immunology. 2017;151(2):154-66. https://doi.org/10.1111/imm.12719.

23. Sassa MF, Saturi AE, Souza LF, Ribeiro LC, Sgarbi DB, Carlos IZ. Response of macrophage Toll-like receptor 4 to a Sporothrix schenckii lipid extract during experimental sporotrichosis. Immunology. 2009;128(2):301-9. https://doi.org/10.1111/j.13652567.2009.03118.x.

24. Sassa MF, Ferreira LS, Ribeiro LC, Carlos IZ. Immune response against Sporothrix schenckii in TLR-4-deficient mice. Mycopathologia. 2012;174(1):21-30. https://doi.org/10.1007/ s11046-012-9523-1.

25. Kajiwara H, Saito M, Ohga S, Uenotsuchi T, Yoshida S. Impaired host defense against Sporothrix schenckii in mice with chronic granulomatous disease. Infect Immun. 2004;72(9):5073-9. https:// doi.org/10.1128/IAI.72.9.5073-5079.2004.

26. Rossato L, Santos SSD, Ferreira LG, de Almeida SR. The importance of Toll-like receptor 4 during experimental Sporothrix brasiliensis infection. Med Mycol. 2019;57(4):489-95. https://doi. org $/ 10.1093 / \mathrm{mmy} / \mathrm{myy} 048$.

27. de CNT, Ferreira LS, Arthur RA, Alegranci P, Placeres MC, Spolidorio LC, et al. Influence of TLR-2 in the immune response in the infection induced by fungus Sporothrix schenckii. Immunol Investig. 2014;43(4):370-90. https://doi.org/10.3109/08820139. 2013.879174.

28. Rossato L, Silvana Dos Santos S, Ferreira LG, Rogerio de Almeida S. The impact of the absence of Toll-like receptor-2 during Sporothrix brasiliensis infection. J Med Microbiol. 2019;68(1): 87-94. https://doi.org/10.1099/jmm.0.000876.

29. Kashem SW, Igyarto BZ, Gerami-Nejad M, Kumamoto Y, Mohammed J, Jarrett E, et al. Candida albicans morphology and dendritic cell subsets determine $\mathrm{T}$ helper cell differentiation. Immunity. 2015;42(2):356-66. https://doi.org/10.1016/j.immuni. 2015.01.008.

30. Delsing CE, Becker KL, Simon A, Kullberg BJ, Bleeker-Rovers $\mathrm{CP}$, van de Veerdonk FL, et al. Th17 cytokine deficiency in patients with Aspergillus skull base osteomyelitis. BMC Infect Dis. 2015;15:140. https://doi.org/10.1186/s12879-015-0891-2.

31. Verdan FF, Faleiros JC, Ferreira LS, Monnazzi LG, Maia DC, Tansine A, et al. Dendritic cell are able to differentially recognize Sporothrix schenckii antigens and promote Th1/Th17 response in vitro. Immunobiology. 2012;217(8):788-94. https://doi.org/10. 1016/j.imbio.2012.04.006.

32. Patel DD, Kuchroo VK. Th17 cell pathway in human immunity: lessons from genetics and therapeutic interventions. Immunity. 2015;43(6):1040-51. https://doi.org/10.1016/j.immuni.2015.12. 003.

33. Ferreira LS, Goncalves AC, Portuondo DL, Maia DC, Placeres MC, Batista-Duharte A, et al. Optimal clearance of Sporothrix schenckii requires an intact Th17 response in a mouse model of systemic infection. Immunobiology. 2015;220(8):985-92. https:// doi.org/10.1016/j.imbio.2015.02.009.

34. Meena D, Sharma S, Chauhan P. Measles, mumps, and rubella vaccine in genital warts: a case report of two patients. Indian J Sex Transm Dis AIDS. 2018;39(2):133-5. https://doi.org/10. 4103/ijstd.IJSTD_44_16.

35. Lin HX, Ma Z, Yang XQ, Fan HJ, Lu CP. A novel vaccine against Porcine circovirus type 2 (PCV2) and Streptococcus equi ssp. zooepidemicus (SEZ) co-infection. Vet Microbiol. 2014;171(1-2): 198-205. https://doi.org/10.1016/j.vetmic.2014.03.018.

36. Dadar M, Tiwari R, Karthik K, Chakraborty S, Shahali Y, Dhama K. Candida albicans - biology, molecular characterization, pathogenicity, and advances in diagnosis and control - an update. Microb Pathog. 2018;117:128-38. https://doi.org/10.1016/j.micpath.2018. 02.028 .

37. Uppuluri P, Singh S, Alqarihi A, Schmidt CS, Hennessey JP Jr, Yeaman MR, et al. Human anti-Als3p antibodies are surrogate markers of NDV-3A vaccine efficacy against recurrent vulvovaginal candidiasis. Front Immunol. 2018;9:1349. https:// doi.org/10.3389/fimmu.2018.01349.

38. Edwards JE Jr, Schwartz MM, Schmidt CS, Sobel JD, Nyirjesy P, Schodel F, et al. A fungal immunotherapeutic vaccine (NDV-3A) for treatment of recurrent vulvovaginal candidiasis-a phase 2 randomized, double-blind, placebo-controlled trial. Clin Infect Dis. 2018;66(12):1928-36. https://doi.org/10.1093/cid/ciy185.

39. Tso GHW, Reales-Calderon JA, Pavelka N. The elusive antiCandida vaccine: lessons from the past and opportunities for the future. Front Immunol. 2018;9:897. https://doi.org/10.3389/fimmu. 2018.00897.

40. Pappas PG, Lionakis MS, Arendrup MC, Ostrosky-Zeichner L, Kullberg BJ. Invasive candidiasis. Nat Rev Dis Primers. 2018;4: 18026. https://doi.org/10.1038/nrdp.2018.26.

41. Nami S, Aghebati-Maleki A, Morovati H, Aghebati-Maleki L. Current antifungal drugs and immunotherapeutic approaches as 
promising strategies to treatment of fungal diseases. Biomed Pharmacother. 2019;110:857-68. https://doi.org/10.1016/j.biopha. 2018.12.009.

42. Nascimento RC, Almeida SR. Humoral immune response against soluble and fractionate antigens in experimental sporotrichosis. FEMS Immunol Med Microbiol. 2005;43(2):241-7. https://doi. org/10.1016/j.femsim.2004.08.004.

43. Ruiz-Baca E, Toriello C, Perez-Torres A, Sabanero-Lopez M, Villagomez-Castro JC, Lopez-Romero E. Isolation and some properties of a glycoprotein of $70 \mathrm{kDa}(\mathrm{Gp} 70)$ from the cell wall of Sporothrix schenckii involved in fungal adherence to dermal extracellular matrix. Med Mycol. 2009;47(2):185-96. https://doi.org/10. 1080/13693780802165789.

44.• Nascimento RC, Espindola NM, Castro RA, Teixeira PA, Loureiro y Penha CV, Lopes-Bezerra LM, et al. Passive immunization with monoclonal antibody against a $70-\mathrm{kDa}$ putative adhesin of Sporothrix schenckii induces protection in murine sporotrichosis. Eur J Immunol. 2008;38(11):3080-9. https://doi.org/10.1002/eji. 200838513. This paper shows a model of sporotrichosis treatment using the monoclonal antibody P6E7, against gp70. The MAbP6E7 was effective against sporotrichosis in prophylactic and therapeutic models of infection by $S$. schenckii.

45. de Almeida JR, Kaihami GH, Jannuzzi GP, de Almeida SR. Therapeutic vaccine using a monoclonal antibody against a 70$\mathrm{kDa}$ glycoprotein in mice infected with highly virulent Sporothrix schenckii and Sporothrix brasiliensis. Med Mycol. 2015;53(1):4250. https://doi.org/10.1093/mmy/myu049.

46. de Almeida JR, Santiago KL, Kaihami GH, Maranhao AQ, de Macedo Brigido M, de Almeida SR. The efficacy of humanized antibody against the Sporothrix antigen, gp70, in promoting phagocytosis and reducing disease burden. Front Microbiol. 2017;8:345. https://doi.org/10.3389/fmicb.2017.00345.

47. Portuondo DL, Batista-Duharte A, Ferreira LS, Martinez DT, Polesi MC, Duarte RA, et al. A cell wall protein-based vaccine candidate induce protective immune response against Sporothrix schenckii infection. Immunobiology. 2016;221(2):300-9. https://doi.org/10. 1016/j.imbio.2015.10.005.

48.• Chen F, Jiang R, Wang Y, Zhu M, Zhang X, Dong S, et al. Recombinant phage elicits protective immune response against systemic S. globosa Infection in Mouse Model. Sci Rep. 2017;7: 42024. https://doi.org/10.1038/srep42024. This paper shows the developed a potential candidate $S$. globosa vaccine using a recombinant phage with a gp70 peptide. This recombinant phage enhanced Th1 cells and induced a strong humoral response that decreased the fungal load in disseminated sporotrichosis caused by $\boldsymbol{S}$. globosa.

49. Portuondo DL, Batista-Duharte A, Ferreira LS, de Andrade CR, Quinello C, Tellez-Martinez D, et al. Comparative efficacy and toxicity of two vaccine candidates against Sporothrix schenckii using either Montanide Pet Gel A or aluminum hydroxide adjuvants in mice. Vaccine. 2017;35(34):4430-6. https://doi.org/10.1016/j. vaccine. 2017.05.046.

50. Tellez-Martinez D, Leandro Portuondo D, Loesch ML, BatistaDuharte A, Zeppone Carlos I. A recombinant enolase-Montanide PetGel A vaccine promotes a protective Th1 immune response against a highly virulent Sporothrix schenckii by toluene exposure. Pharmaceutics. 2019;11(3). https://doi.org/10.3390/ pharmaceutics 11030144.

$51 . \bullet$ de Almeida JRF, Jannuzzi GP, Kaihami GH, Breda LCD, Ferreira KS, de Almeida SR. An immunoproteomic approach revealing peptides from Sporothrix brasiliensis that induce a cellular immune response in subcutaneous sporotrichosis. Sci Rep. 2018;8(1):4192. https://doi.org/10.1038/s41598-018-22709-8. This paper shows that some antigenic peptides, such as ZR3, ZR4 and ZR8, induced proliferation in $T$ cells sensitized by $S$. brasiliensis and the treatment with these peptides decreased the diameter of the lesions in subcutaneous sporotrichosis.

52. De Bernardis F, Graziani S, Tirelli F, Antonopoulou S. Candida vaginitis: virulence, host response and vaccine prospects. Med Mycol. 2018;56(suppl_1):26-31. https://doi.org/10.1093/mmy/ myx139.

Publisher's Note Springer Nature remains neutral with regard to jurisdictional claims in published maps and institutional affiliations. 